\title{
USA Librarians and IFLA
}

\section{Foster E. Mohrhardt}

Librarians in the United States with their traditional ties to European libraries welcomed with enthusiasm the 1926 proposal for an international library organization. They viewed it as the culmination of their repeated expressions of interest in establishing closer ties with librarians throughout the world. As early as 1877, seventeen U.S. librarians had attended the founding conference of the British Library Association, which was called "the first international gathering of librarians".(1) Then in 1893 Melvil Dewey, president of the American Library Association, hoped that its conference that year could be a world congress of librarians. Six foreign librarians attended, but it was not a major international meeting.

Even prior to these conferences, U.S. librarians on their trips abroad had established continuing ties with their colleagues in other countries. From their beginnings U.S. libraries have been strengthened by books and journals collected abroad The incentives for international interest have been practical as well as philosophical. A first hand report on the scope of a European trip by a U.S. librarian is found in a 1925 paper by Dr. E. C. Richardson, librarian of Princeton University:

"Last year the European visit took seven months. Its occasion was a very direct matter of international library cooperation involving the League Committee, the Brussels Institute and the A.L.A. Its chief by-product occupations were three: the visiting of as many foreign librarians as possible with reference, first, to the coming fiftieth A.L.A. conference, and second, sounding them as to their probable disposition to join with the League Committee and the A.L.A. in making the Brussels Institute a clearing-house of international bibliography; third, seeing as many union catalogs as possible and visiting as many library schools as possible. These objects took us to Paris, Brussels, London, Rome, Geneva, Zurich, Basel, Freiburg (for the twenty-fifth anniversary of the German Library Association), Frankfurt, Berlin, Brussels and Paris again, and various intermediate places."(2)

Canadian as well as U.S. librarians have been active in and served as leaders of the American Library Association. It was at a Montreal Conference of the A.L.A. in 1900 that the organization established a special "Committee on International Cooperation". Dr. E. C. Richardson says: "This was the beginning of organized A.L.A. promotion of international library cooperation."(3) Leaders of the profession were appointed to this committee, and they stimulated such international interest that the 1904 A.L.A. Conference in St. Louis, Missouri, became an informal international meeting. The following resolution, adopted at that Conference, identifies an early A.L.A. desire for a "Federation":

"The American Library Association, at its twenty-sixth annual meeting, held in St. Louis ... has been honored by the presence of distinguished delegates rep- 
resenting the library and bibliographical interests of many of our sister nations, and the association has heard from them with pleasure the suggestion of a federation of the various library associations and bibliographical societies of the world. "Believing that international cooperation, which has already done so much to promote interests common to all nations, may be expected to be effective in the field with which we are concerned.

"Be it resolved, That the incoming Executive Board be requested to appoint a special committee of five to consider plans for the promotion of international cooperation among libraries, that the committee be directed to ascertain whether the library associations and bibliographical societies of other countries are disposed to entertain favorably such a proposal; that the committee be instructed to report to the next annual meeting of the association, with such recommendations as it may deem fit."(4)

An attempt was made to find out how much international interest there might be in formalizing international cooperation. Although there was some interest, particularly in bibliographic projects, there was not enough support from other countries to encourage the A.L.A. to take further action. Americans continued to work cooperatively at the international level, and a large group of Canadian and United States librarians participated in the Brussels Congress of 1910.

Although there is no further evidence of A.L.A. stimulation of cooperation in the next few years, librarians of major U.S. academic and research libraries travelled to Europe on book buying missions. Some became better acquainted with foreign booksellers and publishers than with the librarians of these countries. They felt that an international library organization would have made it easier for them to meet and consult with their professional colleagues.

Individual librarians and library committees during the first two decades of the 1900 's discussed the growing need for more formalized international library cooperation. E. C. Richardson summarized in 1925 the readiness of American librarians to join with librarians in other countries in cooperative work:

"International cooperation, to Americans, begins with the fact that they have been so long and so largely indebted to the courtesy of European libraries for the books and manuscripts needed in their researches. This free service of books has been almost wholly one-sided as a matter of direct use, probably one hundred to one. Very few European scholars use American collections. It is true, of course, that in the intellectual world learned production itself is counted an equal consideration in any cooperative service, but this does not affect the obligation of American libraries to European libraries or their strong general wish to express their sense of indebtedness in some form of reciprocal service.

The American Library Association is the natural but not the only channel of international cooperation as regards libraries. The association is itself international and operates internationally as to Canada. It maintains, moreover, four or five committees concerned directly with international cooperation. 
The possibilities of a wider cooperation with European libraries has often been discussed and operations to meet several of the specific international library needs of American scholars proposed. Some of these could be carried through easily and without large funds by simple organization and cooperation; others call for more money, but would obviously cost much less with organized international cooperation.

The ultimate factor of practical intellectual cooperation in library matters is the organization of the intellectual workers themselves internationally in order to synthesize national experience in direct conference over actual problems. For this, American librarians have organized appropriate committees which stand ready to join with other committees in such conference over library methods, projects, operations, or ways and means. The successful experiences of the United States and Canada together in the American Library Association have produced among American librarians a certain guarded optimism as to the possibilities of a more general cooperation."(5)

Although library leaders in the U.S. had been disappointed by the unenthusiastic response from foreign librarians to their 1904 suggestion for cooperation between library associations, their hopes were again raised by the announcement of the 1926 Prague Conference. Carl H. Milam, Secretary of the American Library Association, was selected to represent the U.S. He had strong international interests; was an expert on the organization and management of library associations, and was influential in American library affairs. He was uniquely qualified to present U.S. interests and to give expert guidance in the deliberations about forming an international association. He was appointed to the Honorary Committee for the meeting. Professor J. Periam Danton, who was an assistant to Carl Milam, says: "When I went to ALA Headquarters in 1930, I was already an 'internationalist,' so I was much gratified to find that Carl Milam was very internationally-minded, and was determined that the ALA should play a strong role in IFLA. In my opinion what we did in and for IFLA in the early days was almost entirely the result of Milam's interest and efforts."(6)

Since the activities of the Prague meeting are reported in other chapters of this history, no attempt will be made to discuss them again here. It should be noted, however, that as a result of Mr. Milam's report to A.L.A. on Professor Henriot's proposal, an invitation was sent to foreign libraries to send representatives to the 50th Anniversary A.L.A. meeting later that same year (1926). The meeting was held in two places - Atlantic City, New Jersey, and Philadelphia, Pennsylvania.

\section{William Warner Bishop}

It is at this point that our review of U.S.library international relations must focus on the American most closely identified with the establishment and nurturing of IFLA. This is William Warner Bishop, the second president of the Federation and the only American who has received that honor. His colleague, Dr. Lydenberg, Director of the New York Public Library, wrote of him: "Few fellow laborers in 
this country have equalled him in contacts with scholars and librarians abroad, none have surpassed him as interpreter to those at home of what their friends are doing overseas, or as a representative over there of the best expressions of the stirrings, hopes, ideals of the tillers of library fields on this side of the water."(7)

Similar views were held by his IFLA colleagues. Marcel Godet commented:

"Président de la Commission pour les relations internationales de l'A.L.A., délégué comme expert par la Dotation Carnegie auprès de la Bibliothèque Vaticane, membre de la Commission des Experts-bibliothécaires de l'Institut international de Coopération intellectuelle, auteur apprécié d'un livre alors récent (the Backs of Books) qui témoignait de la largeur de ses vues, M. Bishop se trouvait mieux qualifié que n'importe qui pour représenter ses collègues des Etats-Unis dans le nouvel organisme."(8)

Very early in his library career (1898-1899) Bishop had the opportunity to study in Rome as a Fellow of the American School of Classical Studies. He later pointed out that this was when he first became concerned with international library cooperation.

Bishop made frequent visits to Europe and became acquainted with library leaders there. However, it was in 1921 when closer association developed while he served as the official A.L.A. delegate to the British Library Association. During this trip he initiated discussions of problems common to librarians on both sides of the Atlantic. Subsequent trips abroad were made in 1922 and 1923-24, when he served as a special representative of the American Library Association. In addition to his foreign travels his early professional experience stimulated a basic concern with international cooperation. From 1902 to 1907 he was on the staff of the Princeton University Library and was encouraged by Ernest Cushing Richardon, the librarian, to develop his international interests. Bishop was most appreciative of Richardson's thoughtfulness in sharing his professional experience abroad and his foreign and American guests with his young assistant.

When Bishop became Superintendent of the Reading Room at the Library of Congress he again was associated with a colleague who would encourage and abet his international interests - Librarian of Congress, Herbert Putnam. It was Putnam, then chairman of the A.L.A. Committee on International Relations, who appointed him to this committee, providing a channel for this special interest and giving him an opportunity to work with librarians in A.L.A. interested in foreign relations.

He left the Library of Congress in 1915 to become librarian of the University of Michigan where he had even greater opportunities to expand his foreign activities. It is interesting to note that two years before the Prague Congress, the American Library Association designated Carl Roden, George Utley and W. W. Bishop as a Special Committee to arrange for inviting foreign librarians to attend the 1926 A.L.A. meeting. Bishop was asked to extend personal invitations while on his 1924 European trip, on which he reports that he "spent much time and energy in promoting this project."(9) 
It was propitious that these arrangements had been made for extensive international attendance at the 1926 A.L.A. meeting since it provided an opportunity to follow up within a few months on the Prague proposals. As a result of Bishop's 1924 European trip and the stimulation of interest in Prague, twenty-one foreign countries sent representatives to the October 1926 A.L.A. Convention. It was also fortuitous that W. W. Bishop with his enthusiasm and international commitment had just become Secretary of the International Relations Committee. In his report on the 1926 sessions Bishop says:

"At Atlantic City a group of foreign delegates met with the Committee on International Relations of the American Library Association for an informal discussion of certain international aspects of library work. This discussion has been reported in the volume containing the Papers and proceedings of the Fiftieth Anniversary Conference, and more fully in a mimeographed pamphlet which was distributed to all those who took part in the conference itself. At the conclusion of the tour, an informal meeting of all those who remained with the tour until its end was held in Washington, at which certain resolutions were adopted requesting that the American Library Association take the initiative in addressing all known associations of librarians to the end that some organization of a more or less formal type might be set up to arrange for future meetings of a similar sort, and to have charge of formal international relations between libraries and librarians. Practically every American librarian who entertained the delegates, or was associated with this tour, has time and time again expressed the feeling that this opportunity to meet and discuss informally the various phases of our work as they present themselves under differing conditions in diverse parts of the world, was one of the most valuable experiences of his professional career. It has been my good fortune to meet a number of the persons who participated in this conference and this tour during a recent visit to Europe. With one accord they are of the same opinion as their American colleagues."(10)

He also remarked prophetically: "That meeting will, I venture to say, prove historical in more ways than one. It seems likely that it will be known as marking the beginning of effective, practical cooperation between librarians of Europe, Asia, North and South America."(11)

We can recapture a sense of the impact which this meeting had on other American librarians by listening to the contemporary remarks of two A.L.A. presidents. Charles Belden, librarian of the Boston Public Library, concluded his 1927 speech, "Library Service in an Understanding World", with a statement about what U.S. librarians should seek in international relations:

"We have much to give, but we have also much to gain. Library methods we do not need to learn abroad - these we can teach - but we can cultitative there our opportunities for scholarship. It was with this in mind that I stressed also the importance of finding new avenues for a broader education through the exchange of students and professors. Greater breadth and depth, not necessarily increased efficiency, are today the fundamental needs of American librarianship; welcome to every agency that helps us.in this direction!"(12) 
Then the next year Carl B. Roden, librarian of the Chicago Public Library, was still so exhilarated that he remarked:

"Our rapidly expanding contacts with librarianship in other countries is a development of recent years that constitutes a significant phase of our own rapidly expanding interests. The distinguished group from beyond the seas that graced our Fiftieth Anniversary Conference brought to many the first vivid realization of our essential kinship in ideals and objectives with our colleagues the world over. American librarianship, fifty years young, was there received into the family of its elder brethren rich in tradition and great in wisdom, and found itself in a company acknowledging a common heritage. It was a revelation that was arresting, chastening, and, let us believe, contributed something to our present mood of selfexamination."(13)

Again we turn to Dr. Bishop for information about the consequences of this historic meeting:

"The most important duty left with the Committee on International Relations and with the American Library Association as a heritage of the Atlantic City Conference was the task of communicating to other library associations the resolutions passed by the group of foreign delegates at Washington on the completion of their trip. With the counsel of the Committee, the President and Secretary of the Association prepared a letter which was sent to all library associations known to us, requesting them to consider the matter of an international committee or an international federation of library associations, and to send delegates to the Edinburgh Conference, to be held next September, prepared to discuss and to act upon such proposals."(14)

Most countries were slow to respond, but this resulted from the careful consideration which they were giving to the proposal. Bishop hoped that the group in Edinburgh would at least set up a committee which would establish some reasonable pattern for calling international meetings.

Bishop was keenly aware of the serious problems that would have to be solved before librarians could establish any permanent organization. When some of the A.L.A. leaders began to speak of their 1926 meeting as an International Congress of Librarians, Bishop frankly pointed out that much more than a title was required to establish a congress or a federation. He stressed the importance of extensive preparation, governmental approval by some European countries, assured financing, and the establishment of a capable secretariat. He insisted that the 1926 meeting should limit its responsibilities to providing an opportunity for informal, frank discussions by international librarians. These talks would form the background for the formal agreements that would be reached in Edinburgh.

$\mathrm{He}$ also felt that any international library association would have to establish ties with existing international bodies. Hence, he brought to the attention of various groups information about the growing interest in a library federation.

Participating in a meeting of the International Institute for Intellectual Cooperation resulted in the following recommendation by its Committee of Library Experts: 
"5. After having heard a statement from Mr. Bishop as regards views exchanged on the occasion of the conference of the American Library Association at Atlantic City in October 1926, with reference to the formation of an international federation of librarians' associations, the Committee of Experts is of opinion that Mr. de Vos van Steenwijk should attend the meeting of the British Library Association at Edinburgh in September 1927 in order to ascertain the progress made in the realization of the proposals. When the matter has assumed definite shape a resolution should be adopted regarding the relations to be established between the new central service at the Institute and the contemplated International Federation of Librarians.

6. The Committee of Experts is of opinion that it is desirable to communicate the above resolutions, on the one hand to the directors of national libraries, and on the other to the presidents of associations of librarians and to bring about an exchange of views on this subject at the forthcoming Edinburgh meeting."(15)

Unfortunately, Bishop could not attend the Edinburgh meeting. The U.S. representatives, as is pointed out elsewhere in this book, were active participants.

Carl Roden was the U.S. representative, chairing the committee which drafted the provisional constitution for the organization. Carl Milam had a prominent position at the meeting and was responsible for the procedures governing the organization. In addition to Milam and Roden, the provisional recommendations were signed by Charles Belden, George Utley, Frank P. Hill and H.H.B. Meyer, representing the American Library Association.

The recommendations for an International Library and Bibliographic Committee were readily approved by A.L.A., which appointed Dr. Bishop as the U.S. representative on the Committee. He was an active participant in the 1927, 1929, $1931,1932,1933$ and 1935 meetings of the International Library Committee. He had accepted in 1927 the responsibility for supervision of the recataloging of the Vatican Library and was in Rome in 1927 and 1928. Financing was provided by the Carnegie Endowment for International Peace. Professor Danton says:

"Bishop could not have done what he did without them (Milam's interest and efforts), and particularly without the financial support Milam secured from the Carnegie Corporation and the Carnegie Endowment for International Peace. Financial support from the latter, for example, made possible the attendance at the IFLA formative session in Rome in 1928 of Milam and the ALA president."(16)

On January 18, 1928 the American Library Association notified the International Committee that the A.L.A. Council had unanimously adopted the Edinburgh resolutions. Dr. Bishop was named as the U.S. delegate. He worked closely with Milam on plans for IFLA. It was Milam who proposed the six committees that were established by the federation. Bishop and Hanson were the U.S. representatives at the first official sessions of the committee which were held in 1928 in Rome. Reporting on his 1928 trip to Rome Bishop says:

"... the fact that Dr. Isak Collijn of Stockholm was in Rome (called in to assist in planning the cataloging of the incunabula) and that Hanson was likewise there led to a meeting of the International Library Committee in Rome."(17) 
He adds:

"To the Carnegie Endowment is due whatever credit exists for my own part in the working of the International Federation of Library Associations. It could not have been performed without the aid very generously given by that organization."(18)

Some illuminating views of these early meetings are provided by one of the participants - Dr. Milton E. Lord, who prepared for this volume "Notes on the U.S. Participation in the Formative Years of IFLA". Referring to the activities in 1927 and 1928 he says:

"In 1927 Bishop had been sent by Nicholas Murray Butler, President of the Carnegie Endowment for International Peace, on a mission to Rome to propose help to Pope Pius XI (himself a former head of the Vatican Library) in connection with the modernization of the Vatican Library. Bishop's share was to recommend modernizing 1) the catalog of the printed books, 2) the catalog of the manuscripts, and 3) the catalog of the incunabula. As I recall it, Bishop involved Collijn with the manuscripts and the incunabula, either one or the other, or perhaps both. Thus Collijn was in Rome often, and it was there that I knew him, when in 1928 I was joined, on leave for the purpose from my post as the first full-time Librarian of the American Academy in Rome, with Bishop, J. C. M. Hanson, Charles Martel, and William Randall on the work with the catalog of printed books."(19)

Librarians in the U.S. were anticipating the 1929 World Congress in Rome, and Bishop was looking forward with enthusiasm to what he hoped would be a landmark occasion for librarians. Arriving by ship at Naples in 1929 he received an urgent message from Collijn to come to Rome immediately to help in straightening out the chaotic condition of the local planning - or lack of planning - for the first IFLA Congress. Speaking of the local secretary of the planning group and the Congress, Bishop said, "A more inefficient man never breathed".

Sparks in his biography of Bishop reports:

"At Rome, he found Collijn, wo had been ill, nearly exhausted, reduced to despair by a combination of Roman heat and the confusion resulting from the incompetent planning of the local committee. No program had been printed, no dates had been set for most of the social affairs, and nothing had been done toward scheduling meetings of sections. Almost immediately upon arrival, Bishop met with Hugo Krüss, Arundell Esdaile of Great Britain, and several American delegates to draw up a program of sorts for the Congress. Also, knowing that a business meeting of the International Library and Bibliographical Committee was a necessary preliminary to the Congress, he drew up an agenda and had it mimeographed at his own expense.

At this business meeting, Collijn presided while Bishop helped Milam act as tem. porary Secretary. The name of the International Library and Bibliographical Committee was changed to International Federation of Library Associations (I.F.L.A.); the Executive Sub-Committee was re-named the International Library Committee; and T. P. Sevensma was elected Permanent Secretary. When financial support of the I.F.L.A. was discussed, Bishop insisted on regular contributions from member 
associations, a provision which resulted in firm financial foundation for the work of the organization. At the business meeting, Bishop presented to the International Library Committee an invitation to hold the next World Congress in Chicago in 1933 ; it was received with enthusiasm, but no action was taken."(20)

Milton Lord's first-hand impressions give us a feeling of the disorganization: "In 1929 IFLA was proposing a first World-Congress of Libraries and Bibliography to take place in Rome-Naples-Florence-Venice under the presidency of Collijn as the President of IFLA. The local arrangements for Italy had been put into the hands of Vincenzo Fago, the head of the official Italian International Exchange Office. Fago was an affable, but non-performing individual, from whom in Stockholm Collijn could get little satisfaction and unresponsive replies. Collijn wrote to me in Rome from Stockholm, imploring me to see what I could do with Fago "try to get him to understand what has to be done to mount a library congress, as is done so well by the A.L.A., as I saw well at Atlantic City in 1926". Unhappily I had little more success with Fago than had Collijn or Sevensma, the first IFLA Secretary-General.

And so the First World Congress of Libraries and Bibliography arrived at its opening day in Rome without even a printed program! The disorganization of the entire Congress was a shambles in respect to learned or professional programs. A few individuals from outside of Italy - primarily from the U.S. had to get together on the side and develop a makeshift program. I recall going to the Palazzo Corsini for the opening session and meeting Fago and others in the entrance hall, Fago remarking: "Signor Lord, it is so hot this afternoon that we have decided not to hold the session"."(21)

Forty U.S. librarians, the third largest delegation, attended the 1929 Rome meeting - exceeded only by Spain and France. The official A.L.A. representatives were Dr. Bishop, C.H.Compton, president of A.L.A.; Carl Milam, secretary; Louis R. Wilson, president-elect of A.L.A.; and Milton E. Lord, Chairman of the International Relations Committee. Ernest C. Richardson and Joseph L. Wheeler were also designated as part of the official U.S. State Department delegation. A review of the papers and discussions shows that there was extensive participation by all of the U.S. attendees. Carl Milam was chairman of an important section on public libraries.

Unfortunately, illness prevented Bishop from attending the 1930 meeting in Stockholm. Sarah Bogle of the American Library Association served as vice-president. Charles Rush was the other U.S. delegate. It was at this meeting that a report by Carl Milam, Chairman of the Committee on Public Libraries, critically discussed the International Committee's apparent lack of interest in public libraries. After pointing out that meetings of the World Federation of Education Associations and the World Association for Adult Education covered topics pertaining to public libraries, he proposed:

"On behalf of my associates in the Public Library Committee (but without their approval, for I have not had an opportunity to consult them) I offer the following recommendations: 
1. That committees of the International Federation of Library Associations be encouraged to give adequate consideration to the public library aspects of the subjects with which they deal.

2. That in planning future library congresses the International Library Committee (a) provide opportunity for the discussion of public library problems, and (b) state in its announcements that the Congress is for library workers from all kinds of libraries and library agencies." (22)

He thus raised a subject which has been a continuing IFLA problem, and affirmative action in 1930 might have forestalled recurrences of complaints by public librarians in the 1950's and 1960's.

W. W. Bishop was Vice President of IFLA from 1929 until 1931 when he became the second president of the organization at the Conference in Cheltenham, England. Bishop reports that he presided for the first time at the International Library Committee meeting in Bern in 1932. Although he had a good working knowledge of French, German and Italian, he found it a difficult task to handle a meeting where they were all "freely used", and he expressed his great appreciation for the help of Sevensma.

As president of an organization which was so important to him, he tried to raise funds to bring the International Committee to Chicago in 1933 for the A.L.A. meeting, Only a limited amount of money was raised, and not all of the members could come. Those who were in Chicago held the sixth International Library Committee session with the A.L.A. International Relations Committee on October 14. The members were jointed by thirty-one delegates from seventeen countries. The Federation also had a meeting in Avignon in November - the only year when IFLA had meetings in more than one country. Mr. Godet presided in Avignon since Bishop could not attend.

Again Milton Lord gives us a personal report:

"Bishop succeeded Collijn as President of IFLA. Already Bishop had scored a sort of triumph - with the aid of some of the foundations - in getting a respectable representation of leading European librarians to the U.S. for holding in Chicago in 1933 a session of the IFLA International Library Committee (as the IFLA Board was then known) - more or less in conjunction with the Chicago World Fair of that year. This offered a background for the soon-to-come Second World Congress of Libraries and Bibliography at Madrid-Sevilla-Barcelona in 1935, presided in elegant fashion by Bishop, with a goodly turn-out of U.S. librarians. Good program sessions were held, as a result of Bishop's solicitude that there should be such, and there were visits to the great Spanish libraries and collections.

I recall a sticky moment at the closing session in Barcelona when the time came for offering an invitation for the next World Congress of Libraries in 1940. Krüss, the Generaldirektor of the Preussische Staatsbibliothek in Berlin, jumped to his feet with an invitation to Germany in 1940. There was considerable anti-Nazi feeling among those present (almost entirely European librarians). A tense moment ensued. Finally Milam saved the day by suggesting that the invitation be accepted "en principe", leaving to the IFLA Bureau the taking of the matter thereafter. 
But, like the Rome-Naples-Florence-Venice Congress of 1929, the Madrid-SevillaBarcelona Congress of 1935 did not have the results hoped for. It was followed almost immediately by the outbreak of the Spanish Civil War. Publication of the proceedings went into abeyance. I had, for instance, prepared two separate papers that I had given, but I never knew whether they reached publication."(23)

Prior to the 1935 Madrid meeting Bishop had told Milam that he planned to resign in Madrid from his IFLA presidency and his place on the International Library Committee. He hoped that a younger librarian would be appointed to represent the U.S. In announcing his resignation at Madrid he stated his belief that the presidency should not remain too long in the hands of any one country. He was persuaded to remain in office until the Warsaw meeting the next year. He could not attend the 1936 Warsaw session. Charles Rush of Yale University was selected on Bishop's recommendation as the U.S. representative.

Bishop's resignation was graciously accepted by Vice President Godet. Although Bishop did not attend any other IFLA meetings, his term as A.L.A. representative to the I.L.C. continued until 1939, and at that time the A.L.A. Executive Board re-elected him for the term expiring at the end of 1941. The A.L.A. Executive Board in 1945 elected him representative emeritus. He remained active in committee work and was called upon regularly by IFLA officers for advice on many subjects including documentation, conferences and committee appointments.

Milton E. Lord, Director of the Boston Public Library, succeeded Bishop as Chairman of the A.L.A. International Relations Committee in 1934. Mr. Lord had studied in Paris, and had served as librarian of the American Academy in Rome. He had attended the 1st International Congress in Rome in 1929. Mr. Lord was outstanding among the younger American librarians. He was a member of the official delegation to the 1935 Congress in Madrid and was an active participant in the section on cooperation between countries, and presented a paper on "Union Cataloging in the United States". His notes provided for this chapter bring a vital sense of the early IFLA problems and activities. The late 1930's were crucial years for IFLA as he notes:

"In due season Marcel Godet, the Director of the Swiss National Library in Berne, succeeded Bishop as President of IFLA. Godet, together with Sevensma at the U.N. Library in Geneva as Secretary-General and Arthur Breycha-Vauthier, the No. 2 man at the U.N. Library, kept the lines of the annual sessions of the International Library Committee intact until World War II broke out, and thereafter held the threads together all through the war period."(24)

Official U.S. delegates to the 1937 Paris meeting were Ms. J. Meyer and J.T.Vance; to the 1938 Brussels sessions, Ms. J. Meyer; and to the 1939 Hague meeting H. Craver and J.P. Danton.

Carl Milam and W. W. Bishop, the longtime A.L.A. supporters and proponents of IFLA, came to a serious disagreement about the Federation in the years following the 1935 IFLA meeting. It concerned the problem of selecting a country for the 1940 conference, mentioned by Mr. Lord in the previous quotation. As Lord in- 
dicates, Milam had suggested in Barcelona that the utimate decision on the 1940 site be left in the hands of the IFLA Bureau. Sparks in his biography of Bishop gives an account of the controversy:

"His (Bishop's) greatest single service to the IFLA after his resignation from the presidency was in connection with the choice of a meeting place for a World Congress of librarians planned for 1940. It is perhaps not too much to say that he saved the organization from probable demise - certainly from extended contro. versy - by successfully opposing unwise action proposed by the A.L.A. officers and Executive Board....

As presiding officer at the Madrid meeting, Bishop did not take sides in the matter, but his feelings were not neutral. He had hoped that the British delegates would come forward with an invitation, thus giving the organization a choice between Germany and Britain. After the Madrid Congress, he set to work quietly to elicit a British invitation, even securing an informal promise of financial aid from the Carnegie United Kingdom Trustees."(25)

The British did not want to engage in a controversy about the location of the meeting. They indicated a readiness to extend an invitation to hold the meeting in Britain - only after the German invitation had been rejected. The German librarians stated that if this happened, their government would force them to withdraw from IFLA.

Nearly everyone regarded this possibility as tragic, since the willing spirit of international cooperation displayed by the German librarians had been a moving force in the organization.

"Carl Milam, who was rabidly opposed to accepting the hospitality of a government that nullified and ridiculed most of the ideals cherished by American librarians... expressed his feelings freely to the British librarians and to Godet and Sevensma ... It would be a shame if the Germans withdrew, he said, but it would be far worse to fail to protest the actions of the Nazis. Bishop agreed in private with some of Milam's feelings, but he was distressed by the Executive Secretary's letters to the European librarians. While an American rejection of Germany as a meeting plaee might retain a sense of independence and self-respect for the Americans, it would make trouble for the German colleagues who were laboring to uphold the old traditions of scholarship and service which had distinguished German librarianship, he thought."(26)

The A.L.A. Executive Board passed a resolution:

"Whereas, complete freedom of investigation and expression is the basis of scholarship, in which libraries exercise so large and necessary a part and, Whereas, the Government of Germany through its official actions, has so seriously interfered with this freedom, therefore, Be it Resolved, that the Executive Board of the American Library Association in. struct its representative to vote against acceptance of the invitation of the German Government to hold the 1940 Congress of the International Federation of Library Associations in Germany."(27) 
When word of this action reached Bishop, who was in Florida recuperating from an illness, he telegraphed Milam to delay publishing the resolution, and wrote Harrison Craver, president of A.L.A.:

"The International Federation is the one channel of international participation in library affairs remaining to German librarians. They have been withdrawn by governmental action from practically everything else. Their position is vastly more difficult than most of us realize ... .

I have given time, strength and money to the task of representing the A.L.A. in the International Committee. I served for five years as President of the International Federation, and have now been made an Honorary President of the Federation...

Craver, sympathetic with Bishop's viewpoint, expressed hope that the resolution could be killed ...

Meanwhile, Wilhelm Munthe, who had received an expression of Milam's opinions, took much the same stand as Bishop. The IFLA must not break with the German librarians for three reasons he wrote Bishop: The German librarians as a body and as individuals had done their best to protect freedom to read and freedom of the press; the German withdrawal from IFLA would mean irreparable loss to the small, progressive European countries who were indebted to German colleagues for both personal assistance and loans of materials; and the IFLA would die. Munthe said, 'The result would be that the International Federation; conceived in Philadelphia, born in Edinburgh, and christened in Rome, would now be killed in America. That must be prevented by all means and $I$ hope you will do your best to find a way out of this difficulty.'(28)

At the midwinter meeting of the Executive Board the preamble to the resolution was rescinded, and its action read simply,

VOTED, that a representative on the International Library Committee be informed that the Executive Board does not at this time favor accepting an invitation to hold the International Library Congress in Germany in 1940."(29)

When Marcel Godet in 1938 sent out a request for votes by members, the new invitation was from the two German library associations.

Bishop told Craver that the new invitation should influence the Executive Board to change its position.

"But if the Board vote was still averse to accepting the invitation, he said, the response to Godet should be merely a refusal to vote favorably on the selection of Germany as a site ... Bishop was convinced by May, 1938 that the Congress could not actually take place in Germany anyway ... .

The Executive Board decided at Kansas City in June to accept the German invitation. Bishop communicated the final decision to Sevensma with a sense of great relief ..."(30)

Then at the 1938 Brussels meeting discussions were "diplomatically turned ... to the practical side of the Congress". Bishop told Wilhelm Munthe, when he heard of the harmony at Brussels: 
"My own difficulties in the matter of the invitation to hold the next meeting in Germany have been very considerable, but I managed to get an approval of the invitation from the Executive Board of the A.L.A. ..."(31)

During the war years Bishop found it more and more difficult to correspond with IFLA colleagues. He tried to keep A.L.A. interested in IFLA and insisted that the Association budget its full dues for 1940. "As late as February, 1941, Bishop was considering setting up a working branch of the I.F.L.A. in America for temporary purposes, with the aid of some Latin American librarians, perhaps under himself as Honorary President."(32) The U.S. entrance into the war nullified that plan.

His influence in IFLA has been a continuing one. Three of the five A.L.A. representatives who served as first vice presidents of IFLA had been students in his classes at the University of Michigan - Bryant, Dalton and Mohrhardt.

Milton Lord's reminiscences on the post World War II period are significant: "At the end of World War II there had to be an entire re-building of IFLA. In December 1946 an informal rump session was held in Geneva to consider getting IFLA back onto its feet. Attending were Munthe from Oslo, Sevensma and BreychaVauthier (the former from Holland and the latter being already in Geneva), Mlle Foncin in representation of Julien Cain, the Administrateur-Général of the Bibliothèque Nationale in Paris, and three of us from across the ocean who were in Europe in attendance at the First General Conference of Unesco in Paris - Miss Gill from the National Research Council of Canada, Carl Milam, and Milton Lord.

The outcome was that a revival of the annual IFLA International Library Committee meeting would be attempted in the following spring of 1947 at Oslo. Munthe would be proposed as the IFLA President, Lord as First Vice President, Sevensma and Breycha-Vauthier as Secretary-General and Associate SecretaryGeneral respectively.

The session at Oslo was held in May 1947 amid hope for the future. IFLA was on its way again, still in the hands of the Old Guard. I recall sharing a room with Godet, who for some reason took a fancy to me as "the most European of the American librarians". At that time, so close to the end of the war, everyone in Europe looked hopefully toward the U.S. as the saviour of the future, including the welfare of IFLA. Everyone yearned to come to the U.S. for another World Congress of Libraries.

The 1947 session at Oslo was followed by a London session in 1948 and a Basel session in 1949. Great interest was developing in the possibility of convening the Fourth World Congress of Libraries in the U.S. in 1950 after the long gap since the Congress in Spain in 1935. Unhappily this could not be worked out in the face of the economic problem of getting enough European librarians to the U.S. to prevent such a Congress from being nothing but another A.L.A. type of gathering dominated numerically by U.S. librarians. At the time European currencies were not in a condition to permit most European librarians to travel so great a distance and at so great a cost per individual. Transatlantic air travel had not be. 
come freely available at affordable round-trip rates as today. Attempts were made in vain to obtain travel subsidies from some of the more likely great U.S. foundations. And so to the great disappointment of the IFLA Old Guard the hoped-for U.S. World Congress of Libraries did not come into being at that time.

Thereafter my own direct relationship with IFLA ceased. My period as a formal officer of IFLA was confined to only one term as First Vice President, beginning in 1947 and extending into the very early 1950s. In succession there followed the Vice Presidencies of Bryant, Mohrhardt, Vosper, et al from the side of the U.S.

A strong impetus to IFLA did indeed come out of the U.S., particularly following its inception in the years succeeding to the international gathering of librarians (especially Americans and Europeans) at the A.L.A. 50th Anniversary Conference at Atlantic City in 1926. It was stimulated in most honorable fashion by Bishop, with sympathetic support and interest from key people in the U.S. library world. I recall the presence at Rome of Bishop, Putnam, Milam, Keogh, Belden, and Lord, and at Madrid Wilson, Compton, Milam, Lord, and a number of U.S. librarians on European travels. In the early years following Atlantic City and Edinburgh and thereafter the annual sessions of the International Library Committee were generally graced by the presence of an A.L.A. representative, frequently a U.S. librarian on travel in Europe at the time. At the close of World War II Milam and Lord helped to put IFLA back on its feet again. And from then on there was pretty generally a succession of First Vice Presidents from the U.S. - a Lord, a Bryant, a Mohrhardt, a Vosper, and others."

Dean Jack Dalton of Columbia University, while serving as a U.S. representative and IFLA Vice-President, noted that in the period up to 1940:

"There was apparently no general discussion setting down the areas in which the Federation and its Committee would concentrate their work; rather, Sub-Committees were formed and discussions arose as a result of random suggestions from interested individuals and from other organizations, as well as from the Executive Committee or the International Library Committee as a whole."(34)

He has also noted that even in the 1950's and 1960's U.S. librarians attending IFLA meetings were dismayed to find that many of the activities lacked planning and organization. It was not uncommon to find that meetings listed in the official program were abruptly cancelled - or at times those scheduled to conduct the meetings did not appear.

He reported to the A.L.A. International Relations Committee in 1960 that Douglas Bryant of Harvard University, his predecessor as U.S. delegate to IFLA, had identified IFLA's problems and had recommended stronger A.L.A. participation.

"Mr. Bryant reviewed for the Executive Board the ALA's relations with IFLA since its establishment. He said that the part played by American members (ALA, SLA and MLA) has been substantial but that it has become increasingly important for American librarianship to be influential in IFLA. 
He said that there were six official European delegations at Brussels, active and well-coordinated. It is to ALA's interest to see that American influence and thinking are brought to bear to the fullest extent possible.

One need, Mr. Bryant pointed out, is for greater planning and coordination on the part of American representatives, whether they be from ALA or from the other two associations. An attempt to provide such coordination before the Brussels conference did not get far."(35)

During their terms as Vice Presidents of IFLA both Bryant and Dalton worked within A.L.A. for increased U.S. participation and within IFLA for better organization and management. The 1960's were transitional years for IFLA, when increased participation and wider representation were reshaping the association. Attempts to amend or modify the IFLA organization and activities in the latter part of the 1960's did little to solve the basic problems and pointed to the need for complete reevaluation of the purposes of IFLA and complete reorganization. Robert Vosper who became the U.S. representative in 1971 canvassed all interested groups in the U.S. and presented the criticisms, hopes and recommendations of his colleagues. His special talents as a diplomat were urgently needed and widely used by IFLA in the critical years of reorganization.

\section{Conclusion}

The United States which was so active in the birth of IFLA and at first so proud of the infant federation, later began to look upon it as a distant relative. It was under the direct tutelage and supervision of European librarians, spoke a variety of languages, and was overly concerned with receptions and social entertainment. Some criticized a lack of public library interest, and others complained that IFLA looked at the past rather than the future.

In 1957 an A.L.A. president wrote:

"There is another international organization which we have sadly neglected... IFLA, of which ALA is not only a member but one of the parents. It has had an ALA representative on its governing committee or council from the beginning, but here again a representative without backstopping cannot be effective. So little interest has been shown in the United States in the work of IFLA that within the last year the ALA Executive Board considered a proposal by one of its members that the ALA should discontinue its membership in this international association on the ground that the money could be better spent in some other way! ... It is perhaps incredible that librarians, of all professional people, should have to guard against provincialism."

Many U.S. librarians concerned about international activities have noted a continuing strain of ambivalence in this broad area. There have been strong tides of enthusiasm followed by calm waters of diminished interest. Edward Holley has noted that only once has the ALA "charter been amended ... A.L.A. was granted an amendment to its charter on February 6,1942, which changed "library interest throughout the country' to read 'library interests throughout the world' ..." 
Some U.S. librarians are concerned about the possibilities of overlap and duplication between IFLA and FID. Others wonder about IFLA and Unesco, and the implications of political pressures.

In assigning and outlining this chapter the editor requested a report on the early years of U.S. participation in IFLA. Hence the chapter has emphasized the first decade of IFLA's history. Whoever writes a more comprehensive history of U.S.IFLA relations will show the growing interest and activity of the Canadian Library Association, Special Libraries Association and Association of Research Libraries in the affairs of the Federation. These organizations within the past two decades have contributed greatly to the changes and improvements in IFLA.

Although IFLA is a federation of associations and although the U.S. member associations are forceful parts of IFLA, it is the individuals as participants who have given the real strength to the organization. During periods when the interest of an organization has waned, individual IFLA supporters have continued their professional support and enthusiasm.

\section{Notes}

(1) Belden C. F. D., Library service in an understanding world. In: ALA Bulletin 22. 1928, p. 339.

(2) Richardson E. C., Some aspects of international library co-operation. Yardley, Pa., F. S. Cook, 1928, p. 135.

(3) Richardson E. C., Introductory remarks on "International Libraries." In: Library Journal 59.1934, p. 650 .

(4) Walter F. K., The A. L. A. committee on international relations. American Library Institute Papers and Proceedings. 1919, p. 188.

(5) Op. cit., note 2. pp. 34-37.

(6) Correspondence with Professor J. P. Danton. 1977.

(7) Lydenberg, Harry Miller, William Warner Bishop. In: Lydenberg, H. M. and Andrew Keogh, William Warner Bishop: A tribute. 1941. New Haven, Conn., Yale University Press, 1941, p. 11.

(8) Godet Marcel, Monsieur William Warner Bishop et la Fédération Internationale des Associations de Bibliothécaires. In: Lydenberg, H. M. and Andrew Keogh, William Warner. Bishop: A tribute 1941. New Haven, Conn., Yale University Press. 1941, p. 57.

(9) Bishop W. W., International relations: fragments of autobiography. In: Library Quarterly 19.1949 , p. 279.

((10) Bishop W. W., International relations. In: ALA Bulletin 21. 1927, p. 283.

((11) Op. cit., note 10, p. 284.

((12) Op. cit., note 1, p. 346.

((13) Roden C. B., President's address: ten years. In: ALA Bulletin 22. 1928, p. 317.

((14) Op. cit., note 10, pp. 285-286.

((15) Vos van Steenwijk J. E. de, The International Institute for Intellectual Co-operation. In: Library Journal 53. 1928 , p. 9.

((16) Op. cit., note 6.

((17) Op. cit., note 9, p. 278.

((18) Op. cit., note 9, p. 278

((19) "Notes on the U.S. participation in the formative years of IFLA" prepared for this volume in 1977 by Milton E. Lord. 
(20) Sparks Claud G., William Warner Bishop: a biography. PhD. thesis. University of Michigan. 1967, pp. 441-442.

(21) Op. cit., note 19.

(22) Milam C. H., Report of the committee on public libraries, 1930. In: IFLA Council Actes. 3rd session, Stockholm, 1930, (Annex IV) p. 44.

(23) Op. cit., note 19.

(24) Op. cit., note 19.

(25) Op. cit., note 20, pp. 471-472.

(26) Op. cit., note 20, p. 473.

(27) Op. cit., note 20, p. 474.

(28) Op. cit., note 20, pp. 474-475.

(29) Op. cit., note 20, p. 476.

(30) Op. cit., note 20, p. 477.

(31) Op. cit., note 20, p. 477 .

(32) Op. cit., note 20, pp. 478-479.

(33) Op. cit., note 19.

(34) Memorandum concerning ALA and IFLA by Jack Dalton. Unpublished report to A.L.A.

(35) Op. cit., note 34.

(36) Morsch L. M., Promoting library interests throughout the world. In: ALA Bulletin 51 . 1957 , p. 582.

(37) Holley E. G., ALA at 100. In: ALA Yearbook 1976, Chicago, A.L.A. 1976, p. 5. 